\title{
How art practices can commit to the pursuit of social and environmental justice - from and beyond the civil contract of photography, lessons from the Amazon
}

\section{Como as práticas artísticas podem se comprometer com a busca da justiça social e ambiental - a partir e além do contrato civil de fotografia, lições da Amazônia}

\author{
Marilene Cardoso Ribeiro \\ $\mathrm{PhD}$ Creative Arts, University for the Creative Arts - UCA, UK. \\ Lecturer, Pontifícia Universidade Católica de Minas Gerais - PUC Minas, Brazil. \\ mcardosoribeiro@gmail.com
}

\begin{abstract}
This paper seeks to reflect on the political agency of artworks as well as to propose insights towards potential ways photography could be employed, in the context of the twenty-first century, to support the development of fairer future scenarios in social and environmental agendas. It draws upon the author's experiences in her fieldwork in the Amazon intertwined with Ariella Azoulay's assertions on photographs as agencies of empowerment, and Jacques Rancière's perspectives on the impact of art practices upon the systems that rule society.
\end{abstract}

Keywords: Photography; Photography; Environment; Social Justice; Amazon.

\section{Resumo}

Este artigo procura refletir sobre a atuação política das obras de arte, bem como propor insights sobre possíveis maneiras de empregar a fotografia, no contexto do século XXI, para apoiar o desenvolvimento de cenários futuros mais justos nas agendas sociais e ambientais. Ele se baseia nas experiências da autora em seu trabalho de campo na Amazônia, entrelaçadas com as afirmações de Ariella Azoulay sobre fotografias como agentes de empoderamento, e as perspectivas de Jacques Rancière sobre o impacto das práticas artísticas nos sistemas que governam a sociedade.

Palavras-chave: Fotografia; Desenvolvimento; Justiça Social; Amazônia.

\section{THE BACKGROUND}

We are living in a pivotal moment in which conditions on Earth are changing dramatically, mostly as a consequence of human activities. It has has been so conspicuous that it has led scientists to perceive it as a new geological era: the Anthropocene (ARTAXO, 2014; SUBRAMANIAN, 2019). It describes challenging times where climate change, the overexploitation of natural resources, ecosystems, and specific human groups has become untenable, compromising the resilience of biological systems, human beings' welfare, food and water supplies. Studies have shown that natural phenomena, economics and social life are all part of a single and very fragile network that is not constrained to geographic or political borders (e.g. DURAN, 2017; INPE, INPA, IMAZON, 2018; ALLEMAND and OSBORN, 2019). Therefore, it would be naïve to think that the issues that afflict Africa, Asia, or Latin America do not concern ordinary citizens, police- and 
decision-makers living or acting in other countries. In other words, regardless of nationality or the actual location of any individual, the concern about socio-environmental issues is critical, as their consequences will impact everyone over time.

Additionally, it has been officially recognised that every human being, as well as every other creature that shares this planet with our species, should be provided with the conditions for them to thrive (see: United Nations, 1948; Constituicíon de la República del Ecuador, 2008, pp. 11 and 33; GUDYNAS, 2015). Thus, caring for others is not only a matter of Ethics or empathy but of social and environmental justice, ultimately. Nevertheless, around the globe, we have witnessed desolating scenarios, and political decision-making that seems to lead in the opposite direction (e.g. BRANT and WATANABE, 2019; FRIEDMAN, 2020; HELM, 2020; ROTH, 2020). In these times, when we, ordinary citizens, seem to feel powerless before agreements and policies that have an impact upon our and other's lives, we may find ourselves wondering: what can we do to influence this situation? Can we, ordinary citizens, do anything to get involved in the change?

I argue that we can and, amidst other potential fronts of engagement in this struggle aiming for social and environmental justice, I consider image-making of particular importance: this paper discusses why and how this is so, as well as proposing insights towards potential ways photography could be employed, in the context of the twenty-first century, to support the development of fairer future scenarios within the social and environmental agendas. My rationale is based on critical publications that have discussed the role of artworks/photography in the way our society operates (and changes) and on the resonances of my practice. Building upon my practice, this article concentrates on my case study in the collaborative work I undertook in the Amazon region, as part of the long-term project Dead Water.

Amongst the urgent matters that populate current news and media globally, several issues have arisen in the Amazon region. One cannot avoid hearing about the conflicts that have afflicted this locality, as they have gained more and more significance in the last decade, particularly in the last year (WATTS, 2014; ANDREONI and HAUSER, 2019; BARROS, SILVA and DOMENICI, 2019; FELLET and COSTA, 2019; United Nations, 2019)

These conflicts are not in any way new, as those who have surveyed this region have chronicled of all these threats (see CUNHA, 1986; FEARNSIDE 1999, 2001; LITTLE, 2014; ALEIXO and CONDÉ, 2015). However, the brutality and the speed at which they advance have escalated exponentially in the last few years (e.g. DOBLAS, 2015; IORIS, 2018; ISA, 2018; VIVEIROS de CASTRO, 2018; BARROS, 2019; FEARNSIDE, 2019).

Most of this imagery of destruction, desolation, grief, death and loss (as much as the images that depict the Amazon as the sublime epitome of lushness, wildness, vastness, grandiosity, of tropical mysteries and lore) has been formed in our minds - in citizens' minds - employing 
photographs. It demonstrates how relevant photography is in shaping our understanding and attitudes (both as individuals and collectively) towards what sits outside ourselves and also how we, viewers, can read between the lines to perceive political norms if looking carefully at the available images.

In 2008, photography theorist and art curator, Ariella Azoulay published a book, The Civil Contract of Photography (AZOULAY, 2008), that has become a cornerstone in the subject of the sociology and the politics of photography in the twenty-first century. In this book, Azoulay turns her (and the reader's) attention to both the viewer and the individual that is portrayed in the photograph, instead of solely praising the sovereignty of the photographer in the realm of photography. Azoulay takes further Roland Barthes' previous reflections on the active role of the viewer in the dialogical phenomenon between photographer-subject-beholder that is mediated by the photograph (BARTHES, 1981). She claims that the condition of being before a photograph, looking at it, is, in fact, an opportunity for the citizenry. As such, she understands that the viewers have to interpret the image they see, to pursue the messages that might be hidden in the interstices of the image, to take a stance regarding the situation they can grasp from that very image (what Azoulay conceives as 'visual citizenship'), instead of restraining one's self in the position of a passive observer.

This interpretation of Azoulay on this 'civil contract' that is articulated through photography as well as the active roles of both 'spectators' and the portrayed subjects is used as a point of departure for the discussions in this article. I also draw upon my experience combining disciplinary knowledge (from Ecology to Social Sciences and Visual Arts), i.e. on my role as 'photographer as expert' (as defined by Dermot Hodson - HODSON, 2019), which places me in a unique position to contribute to the debate on this subject.

In his recently published The Politics of Documentary Photography: Three Theoretical Perspectives (HODSON, 2019), Dermot Hodson, Professor of Political Economy in the School of Social Sciences, History and Philosophy at Birkbeck University of London, acknowledges the power of photographic works in not only surfacing silenced stories and shaping our worldview but in having a stake in the political arena. In his writing, Hodson sets out three ways in which photographers (through their work) have intervened in social and political realms throughout history: (i) as bureaucrats (when image-makers document situations - and end up somehow denouncing them - as staff of governmental agencies), (ii) as advocates (who work along with likeminded actors to advance shared political beliefs), and (iii) as experts (who run interdisciplinary projects, also absorbing to the visual discourse they convey with their cameras technical knowledge from other fields relevant to the subject they portray, bringing together the epistemic community they either belong to or have raised a very close relationship with). Hodson cites Dorothea Lange 
and Sebastião Salgado as 'experts', as, apart from being photographers, they also possess a deep understanding of economics ${ }^{1}$ (the field in which the subject they address in their narratives is embedded). This characteristic of the visual narratives 'photographers as experts' assemble contributes to amalgamate their work as strong pieces in terms of the wealth of information these visual narratives can aggregate in themselves. This constitutes the standpoint from where I develop my arguments in this paper too: as a trained ecologist, an academic in the field of the Arts and Humanities and as a practitioner myself, I understand that my approach - which has been largely focused on addressing themes on identity and socio-environmental issues - is an example of the 'photographer as expert'. My MSc in Ecology, as well as my parallel studies in Visual Anthropology and Social Sciences, have contributed to making the points I raise in Dead Water noted and noticed, as that backs them up. Moreover, in my case, my academic studies have equipped me with a solid understanding of the social and biological contexts in which Dead Water is embedded, what has led me to be invited to present the work in events other than those related to the art and photography circuits only, i.e. this enabled the discourse behind Dead Water to permeate a variety of spaces comprised of audiences from the different social milieu. Also, having been trained in the subject the artwork addresses, exposes and/or questions provides me with information that makes me perceive the bigger picture from the 'expert's' standpoint too; it also makes me consider other variables - which also inspires me to conceive other ways to approach, set up and set out the work, as my mind has been fed with various material to work with, apart from that one restricted to the field of photography.

As such, the considerations and arguments I develop in this writing are underpinned by these foundations and also (as pointed out above) by the experiences I have collected with my practice in the Amazon, notably the one gained from work Dead Water as well as from the resonances of it on both its subjects and the audience.

\section{THE GROUND}

As a consequence of the pressure of the international market, Brazil, like many other countries, has recently been facing an aggressive policy for expansion in hydropower, notably in the Amazon basin (RIBEIRO and BRANFORD, 2019) although hydroelectric power plants have not only disrupted but destroyed much of our freshwater living systems (TSIKATA 2006; XIE et al., 2007; LEES et al., 2016). Up until now, the process of building dams on rivers has fragmented virtually all major river basins in the world (ZARFL et al. 2014; NILSSON et al., 2015; GRILL et

\footnotetext{
${ }^{1}$ Salgado is himself trained as an economist and, in Lange's case, her collaborator and husband, Paul Schuster Taylor, apart from being a writer, is also an economist.
} 
al., 2019;) and impoverished over 400 million people (RICHTER et al., 2010). Above all, the most impressive fact regarding dams and hydropower is the authoritarian way governments, infrastructure companies, and corporations have forced their plans upon nature and communities (PONSETI and LÓPEZ-PUJOL, 2006; TSIKATA 2006; NARMADA 2012; RIBEIRO and BRANFORD, 2019).

In 2011, when the Brazilian president Dilma Rousseff officially announced the controversial Belo Monte hydropower complex would be eventually built in the Amazon, I decided that it was time to take action. Dead Water was my response to this scenario. I have used Brazil as a window on this contemporary and contentious, international issue, which takes place every day in several countries, from China and Russia to Ethiopia and Peru, yet is obscured by the widely spread propaganda representing hydroelectricity as the 'green' and 'sustainable' energy source that may save us from global warming (e.g. NOMBRE, 2014; KUMAR et al., 2016). With Dead Water, I aimed to provoke ordinary citizens (and, whenever possible, decision-makers too) concerning the magnitude of the social and environmental costs of hydro schemes so that this could be one of the steps towards a more ambitious goal: the one in which eventually other, less harmful, forms of energy could be pursued and implemented. My aim was also to expose a system in which a privileged minority (usually those living in developed countries and/or in big urban areas, like São Paulo) get the benefits whereas many others (in this specific case: river basins and riverine lives including those of riverside dwellers - in developing or emerging countries) are usurped, impoverished and damaged in the name of 'the progress', for the 'common good' (as French philosopher Jacques Rancière has put it - RANCIÈRE, 2010), ideas that I will be tackling further on in this paper, in the quest to reclaim a fairer and brighter future.

In summary, Dead Water is a collaborative visual storytelling project I undertook with riverside dwellers that have been affected by hydropower schemes in Brazil. This project has employed image-making and collaboration to access, understand and communicate the environmentally and socially pernicious consequences of these infrastructure schemes (RIBEIRO, 2018). It made sense to me to explore the act of damming a river (as this is a core condition for the hydropower plant to exist) through the experiences of those whom I consider the most appropriate ones to speak about this subject: riverside dwellers. As part of my methodology, I invited individuals to sit for portraits, comprising those who were displaced by the Belo Monte hydropower complex and others dams in Brazil. The Belo Monte hydro complex works ran from 2011 to 2019, on the Xingu River, Pará state, in the Brazilian Amazonia (Fig. 1). Altogether, 94 riverside dwellers participated in this project. For this photoshoot, I asked these sitters to choose a relevant place, as well as to select an object that could represent the feeling(s) they had concerning their respective hydro project. During the shoot (in which I was in charge of operating the camera), I encouraged 
participants to come up with their ideas for their portrait and they could also check and modify the 'framed scene' until they considered the image they saw on the display of my digital camera tallied with what they wanted to present to the viewers. At the same time, by gathering further information and images with participants, we tried to reconstruct sentimental landscapes of their loss. By doing so, participants and I shaped a hybrid perspective: the subject and the photographer worked together, the participants of this project and I assembled stories that intended to set out a narrative about the magnitude of damages that hydropower has inflicted upon nature and people, and also to enable these submerged perspectives to surface. The outcomes of these encounters were shaped in the form of a thesis, written essays, a touring exhibition, a book, and a short film ${ }^{2}$.

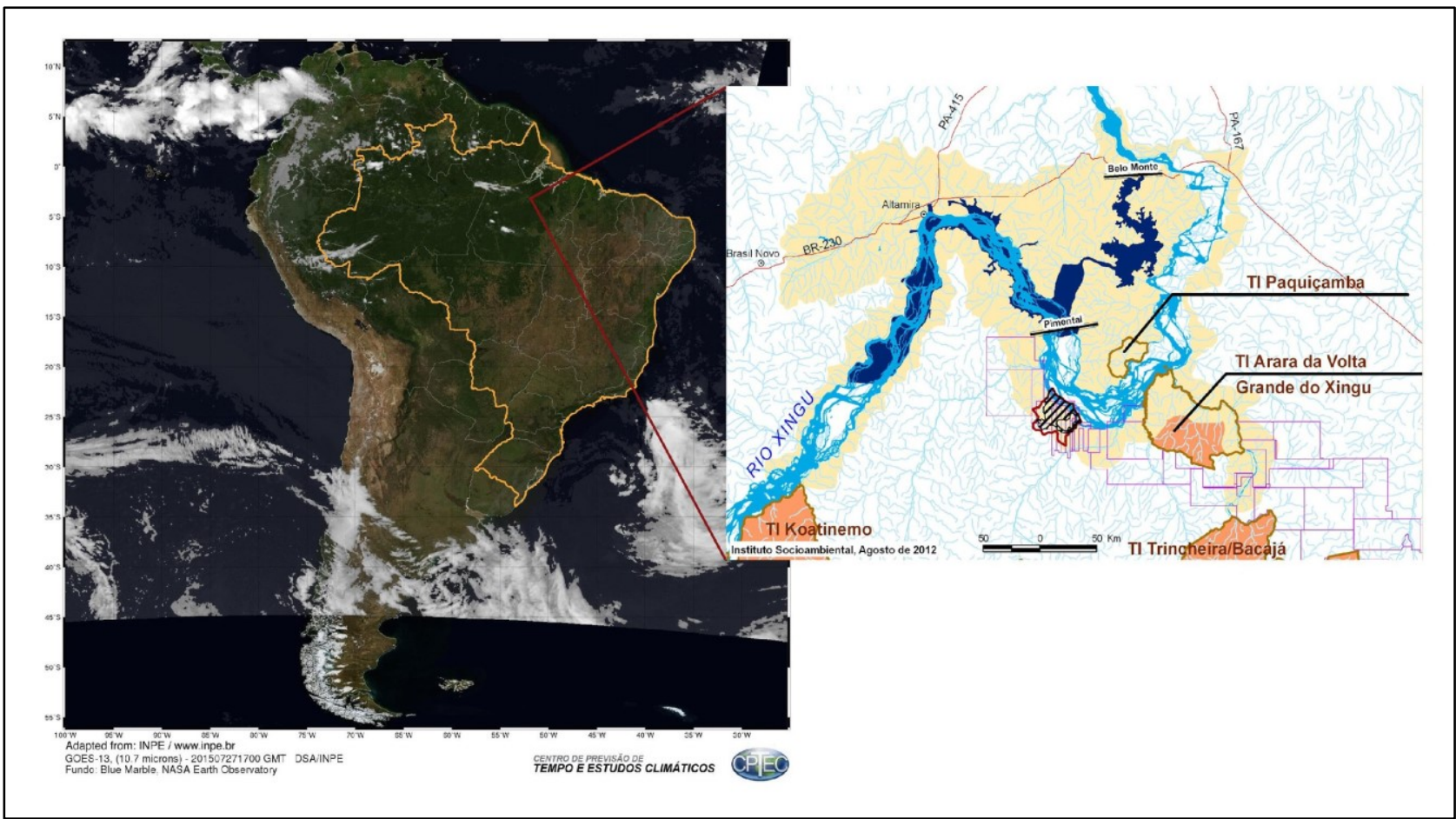

Figure 1 - Location of the Belo Monte hydropower complex (Xingu River, Pará state, Brazil).

On the right-hand side: close-up on the Belo Monte hydro complex. Xingu River depicted in light blue and the reservoirs of the Belo Monte dam complex in dark blue (main reservoir - above-left the Pimental dam in the map, and secondary reservoir - below the Belo Monte dam in the map). Note that the Paquiçamba and Arara da Volta Grande do Xingu Indigenous Reserves are situated within the stretch of the Xingu River that had its average water discharge extremely reduced (up to $80 \%$ ) as a consequence of the Pimental dam upstream, a situation that participant Maria Elite will highlight further on in this paper.

During and after this visual narrative was being put together, I engaged in disseminating the stories Dead Water committed to chronicle. Therefore, I have presented Dead Water in social

\footnotetext{
${ }^{2}$ An overview on the Dead Water project can be accessed at: https://www.marileneribeiro.com/deadwater. The book and the short film Costs can also be accessed respectively at: https://vimeo.com/362012543 and https://vimeo.com/267872971
} 
forums, exhibition spaces, seminars, conferences, workshops, talks, Photography and Film Festivals, magazines, journals and online platforms ${ }^{3}$.

As already stressed above, by having Dead Water as one of the foundations for the topics discussed in this article, I intend to bring out considerations that foreground photographic practices in the political arena. However, this paper does not aim to analyse politics in all its aspects (including the vast arguments that cover its sheer definition). I am rather interested in discussing the role of art/photography in the process of negotiation between individuals and groups, therefore, in politics as its strict (but not less elaborate) definition: the complex or aggregate of relationships of people in society, especially those relationships involving authority or power 4 .

Also, I do not intend to set out here an extensive account of the experiences I have had with both participants and audience of Dead Water, but rather to bring up remarkable examples from these encounters to base my arguments on so that the reader can have a more tangible picture concerning the impact a visual artwork can have on an individual. This includes its expected resonances in future times concerning a fairer landscape for both riverside communities and river basins and their associated wildlife, as I understand that changes operate through a sequence of single steps, even when they can eventually take a form of an insurrection or a revolution.

\section{THE STEMS}

Although the French theorist and philosopher Jacques Rancière deconstructs the term by at the very beginning of his gathered volume Dissensus (2010), affirming that politics is not the exercise of power but rather every ordinary act of every person within a given society - society which is ruled by systems or, as Rancière stresses, 'regimes' (RANCIÈRE, 2010, pp. 27-44), I tend to consider that, despite the author seeming to distance politics from power, he is bringing the latter to the daily individuals' negotiation arena (which is, in the end, organised by those in power, e.g. market demand in the capitalistic society). Also, according to Rancière (2004), the system that regulates aesthetics equips art practices (e.g. photography) with a political agency, i.e. the inherent characteristics of art make its practice able to establish relations between people by making the invisible visible and leading those involved in such negotiation (i.e. producer and recipient) to artmediated actions, what he calls the 'meta-politics of the sensory community' .

\footnotetext{
${ }^{3}$ I also aim to gather participants again in the areas where this work was shot to present the outcomes of this research to them and other locals as well as to discuss with them about their impressions, feelings, and opinions on these results and on how they see these being used next. But this comprises the next stage of the project, which has been postponed due to political, economic (and, now, a world's health) issues that have compromised research and art practices in Brazil since mid 2018.

4 One of the over ten possible definitions by the Collins dictionary. [online] At: https://www.collinsdictionary.com/dictionary/english/politics
}

${ }^{5}$ Meta-politics is defined as a way of doing politics other than the way politics is usually run. 
Ariella Azoulay shares Rancière's vision. During the last twenty years, Azoulay has been working with the role of photography and citizenry in contemporary disasters (with her special interest in the Israeli-Palestinian conflict) and has produced two ground-breaking books: The Civil Contract of Photography (already highlighted in the introduction of this article - AZOULAY, 2008) and Civil Imagination - a Political Ontology of Photography (AZOULAY, 2012). In both publications, she argues that photography can (and must) be used not only to communicate but also to appeal for action concerning 'regime-made disasters' ${ }^{6}$. She acknowledges both subject and viewer as active parts in the process of photography and not mere 'things' that respectively reflect light and passively observe the image but as protagonists that enable the politics through the photography to happen.

This has been a key aspect of my practice (and also of Dead Water); however, the power of art (including photography) in politics is simultaneously always in doubt. Take the American artist and writer Martha Rosler in her striking papers In, Around and Afterthoughts (On Photography) (ROSLER, 1981) and Post-Documentary, Post-Photography? (ROSLER, 2001). Even decades after publication, the rationale presented by Rosler has been taken as the ground to sustain the arguments that photography would not make any difference to the wounds inflicted (and that will continue to be inflicted) by the "regime' ${ }^{7}$. For Rosler and her followers, photography would end up simply documenting these wounds and reinforcing the social and economic extremes it exposes, like a reverse mirror that shows and reminds those before it who (luckily) are not them. Rosler's 'afterthoughts' make even more sense today, considering the interest of photography festivals, gallery dealers and their clients in transforming the 'threats' depicted in the photographic work 'into fantasy' (adopting Rosler's words), or considering the abuse the internet and social media make of socially-engaged/activistic images, shifting the latter from exposé/claim for reaction to commonplace and noise, consequently numbing their audience.

\footnotetext{
${ }^{6}$ According to Azoulay (2008), regime-made disaster is every catastrophe (famine, genocide, oil 'accidents' in the sea, global warming, mining tailing dams collapse, etc.) that consists of nothing else but the outcome of the system (regime) of power in which we live (capitalism, democracy, etc.), i.e. the system operates in a way that either allows or fosters such disasters to happen.
}

\footnotetext{
${ }^{7}$ As noted by the former director of the Cultural Reporting and Criticism Program of the New York University, Susie Linfield, in her book chapter A Little History of Photography Criticism: or Why Do Photography Critics hate Photography?: "[...] But if fewer essays like Sekula's and Rosler's are written now, it is in part because their ideas have been absorbed and accepted by so many in the academy, the art journals, the museums, and the galleries; as theorist W. J. T. Mitchell has written, 'reflexive critical iconoclasm... governs intellectual discourse today.' Thus, in more recent publications, one bumps up against casual phrases like 'the now discredited authenticity once attributed to photography,' as if the question of photography's truth-value has been tossed without regret into the dustbin of history. Even worse are the ways that these ideas have seeped into the general public, encouraging a careless contempt toward documentary photographs. Since such images are cesspools of manipulation and exploitation: why look? It has become all too easy to avert one's eyes; indeed, to do so is considered a virtue. [...]" (Linfield, 2012, p.9)
} 
Nevertheless, scholar and photographer Michelle Bogre (2012) respond to Rosler's arguments by suggesting that photography can make the difference, not as an end but as one of the interconnected means that will eventually lead to change. Bogre reminds us that the photographs from Vietnam changed the public opinion regarding the role of the United States and the heroic look of the war, triggering the anti-war movement. She also cites the working photographer Marcus Bleasdale has done for over ten years: covering the violence inflicted by the Lord's Resistance Army (LRA) upon the civilians of the Republic Democratic of the Congo (RDC). This work (which had been presented at the United States Senate, the United Nations, and Ministry of Foreign Affairs in France) eventually contributed to President Obama signing, in 2010, the bill that pledged for logistic and financial support to put an end to the LRA.

Also, in this regard, in 2012, Aperture Foundation and the Smithsonian Institute published the book Photography Changes Everything with one of its chapters dedicated to stress the power of photography as a relevant tool for change. The author, Frank H. Goodyear III (2012), associate curator of photography of the Smithsonian National Portrait Gallery in Washington DC, like Bogre, acknowledges the impact of photography in the understanding of social (and, I need to add here, environmental) outrages as well as in the struggle for a 'revolution' in the social, political, and economic norms. My understanding is that this has been one of the major uses of photography within social media nowadays (selfies and dairy-related posts apart) - take, for instance, viral photographs (and videos) that uncover appalling facts, which then motivate people to sign online petitions that urge for the ban of plastic bags in the oceans or to demand an end to racism publicly.

Regarding these reflections, photographer Susan Meiselas also notes images as potential igniters of transformation in society, arguing that: Photography can influence how we see, think, understand and perhaps at times engage or act. We simply cannot always measure or trace how it works on our minds and actions.” (MEISELAS, 2017, unpaginated)

Unfortunately, most socially and/or environmentally engaged photography works do not cause such quick responses from either society or decision-makers, they rather become one of the steps in a long process that can take decades, or even centuries to transform a specific matter (and, as Meiselas has stressed above, the participation of photography in such transformation would happen through paths that are usually difficult to track). Nevertheless, as part of the process, they are necessary for the change to happen. Hence, this kind of work must be undertaken as we, individuals living in society, need to see ourselves as part of the system, i.e. part of the problem and its accomplices too (but also part of the solution, as Bogre and Goodyear III have illustrated). I 
would like to reinforce the above considerations by using some examples from the dialogues Dead Water has enabled ${ }^{8}$.

A couple of days after having had Costs screened in the United Kingdom as part of an Eco Cinema Programme, the organiser of that event forwarded to me an email she had received from one of its attendees:

Dear A. [organiser of the Eco Cinema], this petition came to me on the email this morning from Avaaz. This particular petition is directly related to the Eco Cinema topic screened last Tuesday - 'Costs' - by Marilene Ribeiro - which I felt made a huge impact on us all. In this email, Avaaz will petition the Indonesian government not to proceed with a Hydroelectric dam which will severely impact this Orangutan group. They need as many people as possible to sign the petition. [...]

(excerpt from L. C.'s email on 02 August 2018)

L. C. not only openly acknowledges the impact of the film upon the audience but also signposts that Costs has somehow impelled herself to get involved with and gather more people to work towards a change in the system (which, in this case, has to do with the energy agenda and the destruction associated with political deals concerning hydro endeavours).

Visitors' books of the exhibitions of Dead Water, apart from informing the number of people that came to see the work, have also registered an expressive number of statements that showcase the capacity of the visual narrative in provoking the viewer mentally and emotionally, and how the photographic work has prompted the spectator to a response (e.g. Fig. 2).

I shall transcribe a couple of these testimonials below:

The indignation portrayed in works like this one makes us reflective and strengthen the fight for an environmentally sustainable world in where life in its all forms shall be respected.

(A. R. in Dead Water visitors' book on 30 March 2019, p.16)

This work is wonderful. I had seen it already in the Tiradentes Photography Festival this year. [...] It is difficult for the photographer to manage to interact with the sitter in such a profound way as I have seen in this work. It is a beautiful work, yet, the feelings of rage and sorrow subjects have experienced leap from the images to our hearts. Thank you for this experience.

(R. G. in Dead Water visitors' book on 26 June 2019, p.2)

This work transcends photography, it touches souls and sharpens our capacity of fighting against these atrocities.

(L. B. in Dead Water visitors' book on 26 June 2019, p.3)

\footnotetext{
${ }^{8}$ Do I wish I was able to collect all the testimonials that have reached me spontaneously from people who have had access to Dead Water in different occasions (who have watched the film Costs, read the book, articles, essays, visited the exhibition, attended the talks, lectures, accessed the project online, etc.), as their words have been very powerful and moving, thus strengthening the thesis on the agency of artworks in touching the viewer in a way that can make them take another glance at and reflect on the question the former has invited the latter to deal with (i.e. the 'meta-politics', as Rancière has drawn it), but I regret that many times I found myself unprepared to either record or write down most of these viewers' responses to the work at the time they happened.
} 

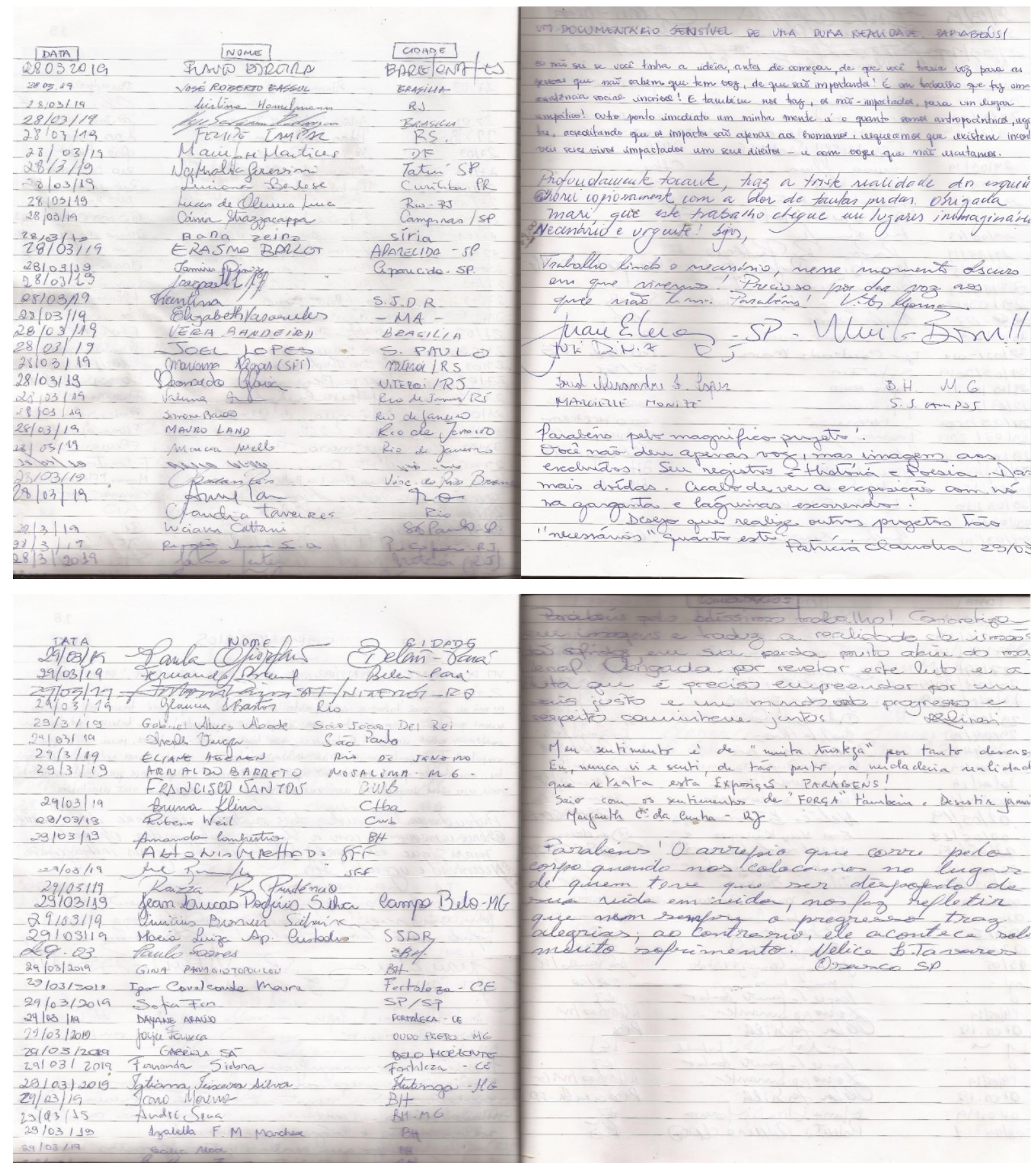

Figure 2 - Visitors' book. Dead Water solo show, Espaço Cultural Quatro Cantos, Tiradentes Photography Festival, Brazil, 2019.

(p.3, 8, 9, 22, respectively - scanned pages)

The impact of the work on viewers has also reached me via other means, like social media as well as personal communication (after the opening of a show, a talk, lecture, screening, etc.). I add to the testimonials above some of those resonances so that the reader can have a stronger picture regarding the points I am articulating in this section.

[On the film Costs] Striking script, innovative, full of emotions, putting subjects' voice their speech - at the core of it. A detailed, articulated film: no faces in it... only the sound of those voices with their melodious accents... and the paradox: chronicling an enormous drama... The black-out takes to push the viewer - us - to the inside of those voices, to the 
inside of those stories, also dignify the stories that are chronicled, what takes the form of an exposé too. I think the filmmaker has achieved her goal: she has touched me.

(message from R. A. to his daughter via social media on 01 March 2018)

It [the film Costs] gives voice to those people who had their lives changed, it takes the point of the environment, the fauna... I'm deeply moved by it...

(message from C. M. to me via social media on 10 February 2018)

When I saw the work [Dead Water], I felt almost moved about the poetic, the wonderfulness of it... It is so moving and special that it kind of fills me, you know... [...] Although it records and talks about a terrible loss, there is always something underpinning it that has to do with a vibrant renewal, and that is what is power, there is where its power lies: to actually show the enormous loss but to somehow draw that in so that you feel it is a kind of way where you connect to the people in it, you connect to it because they [the affected people who participated in the project, the subjects of the photographs] are trying to make something of it. [...] The work is strong because of that, because it says, 'Hey! Look what has happened!'[...]

(J. W., pers. comm. on 16 June 2020)

These examples demonstrate how images have a very peculiar fashion of interacting with our minds (and, as one of the viewers of Dead Water has put it, with our hearts too) and how this can ignite changes in one individual. In other words, this experience with Dead Water draws how images can operate in our society and how every one of us can eventually make the difference and not be only passive 'spectators' of pictures and stories that unfold before our eyes.

I would argue that it also demonstrates that, in contrast to Rosler's concerns ${ }^{9}$ (and also bearing in mind all the constraints with regard to photography and 'reality'), images do have a valuable role in informing people about events and situations, particularly those that take place far from their sight. I understand that visual inquiries, like scientific ones (yet, not intending to place the former within the same scope of reliability and precision of the latter), have the function of disclosing and introducing to the Other (in this case, to the beholder) information, contexts and circumstances (the 'sensible' - as RANCIÈRE, 2004, 2010 - has named it). Consider viewers' testimonials presented above, as well as this very poignant comment below:

The important thing about this work to me is that it makes us think about how much we do not know about rivers, and how we have overlooked them.

(J. M. on 02 August 2018, pers. comm. after the screening of Costs)

Importantly, J. M. openly recognises that the film has enabled him to perceive how rivers and their associated systems operate, i.e. the film as a provider of information to him. Moreover, the

\footnotetext{
9 “ $[\ldots]$ The liberal documentary [the work that is dealt as a commodity by both the media and the art gallery system] assuages any stirrings of conscience in its viewers the way scratching relieves itch and simultaneously reassures them about their relative wealth and social position; especially the latter, now that even the veneer of social concern has dropped away from the upwardly mobile and comfortable social sectors. [...] Documentary, as we know it, carries (old) information about a group of powerless people to another group addressed as socially powerful. [...]" (ROSLER, 1981, p.307)
} 
film enables him to note himself (as a citizen who has not had the chance of perceiving things from this perspective before and who also lives in accordance to the capitalistic society he - and the majority of us - is part of) as an accomplice of the 'regime' that has taken watercourses for granted, then, as a consequence, who has somehow allowed these violent abuses upon these complex ecosystems to happen. Regarding this citizenship of photography, Azoulay (2008) speaks about the urgency of the beholder to take what he/she sees before him/her as something that concerns herself/himself too, once what she/he looks at is a result of the regime-made disaster, is a result of the so-called democratic regime in which we all participate (but some-many? - have no voice). I argue that this kind of reflection and reaction triggered by the artwork (in J. M.'s case, reflection and reaction triggered by the film Costs) would be the first step towards environmental and social justice, as, at the following stage, this process can expand and be turned into action, what may ultimately lead to a re-shaping in political agendas and society.

In this regard, I would like to draw upon French philosopher Bruno Latour's recent reflection. In an interview in El País (BASSETS, 2019) about his latest book Dónde Aterrizar: Cómo Orientarse en Politica (LATOUR, 2019), Latour tells that, when he was flying over the artic towards Canada, he noticed that the ice sheet had shrunk. Then, instead of being astonished by the sublime that, according to him, should consist the view of this vast and beautiful landscape from the above in previous times, he got anguished about what he saw. Especially because he could perceive his own responsibility (as a citizen of the 'Western society') about that unfortunate sight before him, also because, as he noted, the aeroplane that was transporting him at that very moment was releasing greenhouse gases into the atmosphere, so, he was himself, in the end, contributing to global warming and, then, to the tragedy he witnessed from the window of the aircraft ("“...] Si a usted le dicen que es responsable de lo que ve, el sentimiento es distinto, es una forma de angustia. [...]”, Latour cited in BASSETS, 2019, unpaginated).

This image Latour describes could have also been revealed to him not via his first-hand experience but rather through a photograph he came across, one can assume that this photograph could provoke him in a similar way (considering the size of the print and other specifics regarding the atmosphere created to 'receive' its viewer). By sharing a photograph, its author also shares the responsibility about that specific circumstance the photographer transposes to the medium, so that, once that circumstance is presented to its viewer, the latter can no longer claim ignorance concerning the subject depicted. From then onwards, one cannot prevent oneself from considering the reasons for and the consequences of what has been 'eye-witnessed'. Additionally, if what is depicted concerns to a context of deprivation, violence, usurpation, destruction, or unfairness, one 
cannot avoid having at least a mental discomfort ${ }^{10}$ demanding for an inner reaction that could transform that 'reality' into a better one.

Yet, contrastingly from L. C. (p.11), will most of the testimonials of the viewers of Dead Water be turned into any practical action against the impoundment of rivers? Probably not. However, their perceptions of dams, hydro schemes, and the 'green and sustainable' have somehow been shaken and, as public opinion about a given subject is revised, this can ultimately lead to an actual change in the future. This is embedded in the property of artwork to deliver what Rancière (2010) names 'dissensus'.

According to Rancière (2010) the regime in which people interrelate works underpinned by the 'consensus' - something agreed by the whole given community, and reinforced by those who rule such regimes, as the natural order of things, hence, taken as the comfortable truth (e.g. we, contemporary society, need energy; thus we need to cope-and cooperate-with this system in which hydropower is necessary as we cannot see any other better scenario but this one). Dissensus is any proposal that urges for a different rule, disrupting that widely accepted consensus, even if this proposal is conjectural (e.g. hydropower should not be an option as it leads to the dismantlement of the ecological and social network). It might happen that, after some time, this first collectively inconceivable proposal (dissensus) is absorbed and accepted by that given community, becoming a new consensus until the time comes for another dissensus to rise. For Rancière, this is how politics is performed: between this transit and tension between consensus and dissensus ${ }^{11}$. If photography can be a 'place' for dissensus to manifest, thus it is a channel for pleading against environmental and social abuses that are widely accepted as the costs paid for our way of living, or the sacrifices of the 'development' (consensus) as well as for urging for a new order. If photography can embrace dissensus, it is a relevant piece in the process of social, political, and economic change; hence photography may be used thus. If both the environment and specific communities have been overlooked and silenced for the global economic good and this logic needs to be reviewed, then photography can be one of the means towards this redefinition in the social norm. Therefore, if photography holds this capacity of inviting the beholder to the citizenry, to be a protagonist, to be responsible for what takes place on this planet that we share with others, may we, image-makers and viewers, offer photography and ourselves for this purpose.

I perceive Dead Water flowing in the territory of dissensus. The concerns of the people affected by the dams regarding the drawbacks of hydropower (which has been so far widely taken

\footnotetext{
${ }^{10}$ Somehow remembering Rosler's considerations here, yet not intending to restrict the viewer's reaction to a single, flash donation to a charity or any similar punctual attitude.
}

${ }^{11}$ Obviously, this political play is not fixed. It can change over time, as revolutions may occur. 
as an acceptable solution for our need for energy) resonate in work, the thoughts and emotions explored by those who participate in the project and I have been unfolded and exchanged between us. We have learnt from each other, and the work itself speaks to many others. Most importantly, the subjects' voices that raise dissensus are out there.

Bringing to the foreground the active role of the depicted subject in the act of photography (not as a victim but as a citizen who refuses their voice being silenced by what Azoulay and Rancière refer to as 'the regime') and also reflecting on the commitment of the viewer, once before a photograph, Dead Water has affirmed the political attributes of photography as well as its relevance in how we, society, understand things. In Dead Water, those photographed explicitly reclaim their role as committed protagonists within the civil contract of photography as all portraits assembled during my fieldwork are conceived based on each sitter's testimonial and ideas to transpose their thoughts to the final image. In Dead Water, my collaborators ${ }^{12}$ and I have jointly assembled stories that intend not only to set up a visual narrative on the negative impacts of hydroelectric power but also to engage those affected concerning their role as voices for these concealed tensions to the surface, as voices that reclaim Human Rights and the Rights of Nature, and challenge our understanding of dams and the global energy policy agenda. For the purpose of supporting and clarifying the points made above regarding this take of Azoulay's reasoning, I present below some (from the many) situations that unfolded during my fieldwork in the Belo Monte dam area.

Throughout my encounters, the words and postures of participants of Dead Water have been loaded with the overwhelming feeling of violation that the Belo Monte dam project has caused: violation of nature, violation of the affected people's identity, history, culture, and citizenship. Short statements by my collaborators Aronor and José Nunes (both displaced by the Belo Monte dam), during their respective interviews, provide a glimpse of this:

\section{[...] They [Norte Energia] didn't respect anything, either individuals or nature. [...]}

(Aronor, interviewed on 14 October 2016)

[...] What's it like today, the island where we used to live? The one with all the trees, the rubber trees? It's deserted. They [employees of Norte Energia, the company in charge of the Belo Monte dam project] chopped down the trees and buried everything. What they didn't bury, they burnt. When I pass in the boat, I see it. It's just a desert. [...]

(José Nunes, interviewed on 23 October 2016)

Maria Eliete, another subject collaborator in Dead Water, is a teacher and the daughter of Manoel Juruna, former chief of the Paquiçamba Indigenous Reserve. The Paquiçamba Indigenous Reserve (ethnical group Yudjá/Juruna) is located by the Xingu River, downstream of the Pimental dam (the major wall of the Belo Monte dam complex). After describing and detailing the struggles

\footnotetext{
12 i.e. those affected by the hydro schemes surveyed in the project who participated in the making of Dead Water.
} 
her community have endured since the dam project was announced, she speaks of her feelings of desperation and sorrow about Belo Monte. Particularly with regard to the rupture of the characteristic Amazonian cyclic pattern of flooding and drought in that stretch of the Xingu River and the interdependence of seasonal fruit trees and fish life cycles. Usually, from November to March, the discharge of the Xingu River increases considerably, partially submerging trees situated in islands along the river. The fruit yield of these tree species are synchronised with this 'high tide' season in order that fruit fall in the Water by the time they get ripe. As soon as they fall in the Water, fish eat them. Once the water level does not rise anymore (due to the upstream damming ${ }^{13}$ ), these fruits are now falling on the sandbanks that remain constantly exposed. Consequently, the seeds of these trees cannot be dispersed, and fish cannot find food anymore. Fish, once abundant in the area, are now rare. Many fish species are dying from starvation, though a few may manage to migrate. Paquiçamba's dwellers will have to shift their diet and habits, too, as their main source of food/protein is scarce now. On her own portrait, Eliete chooses to highlight these intricate evolutionary connections and the severe damages the Belo Monte dam has inflicted on them (Fig. $3)$.

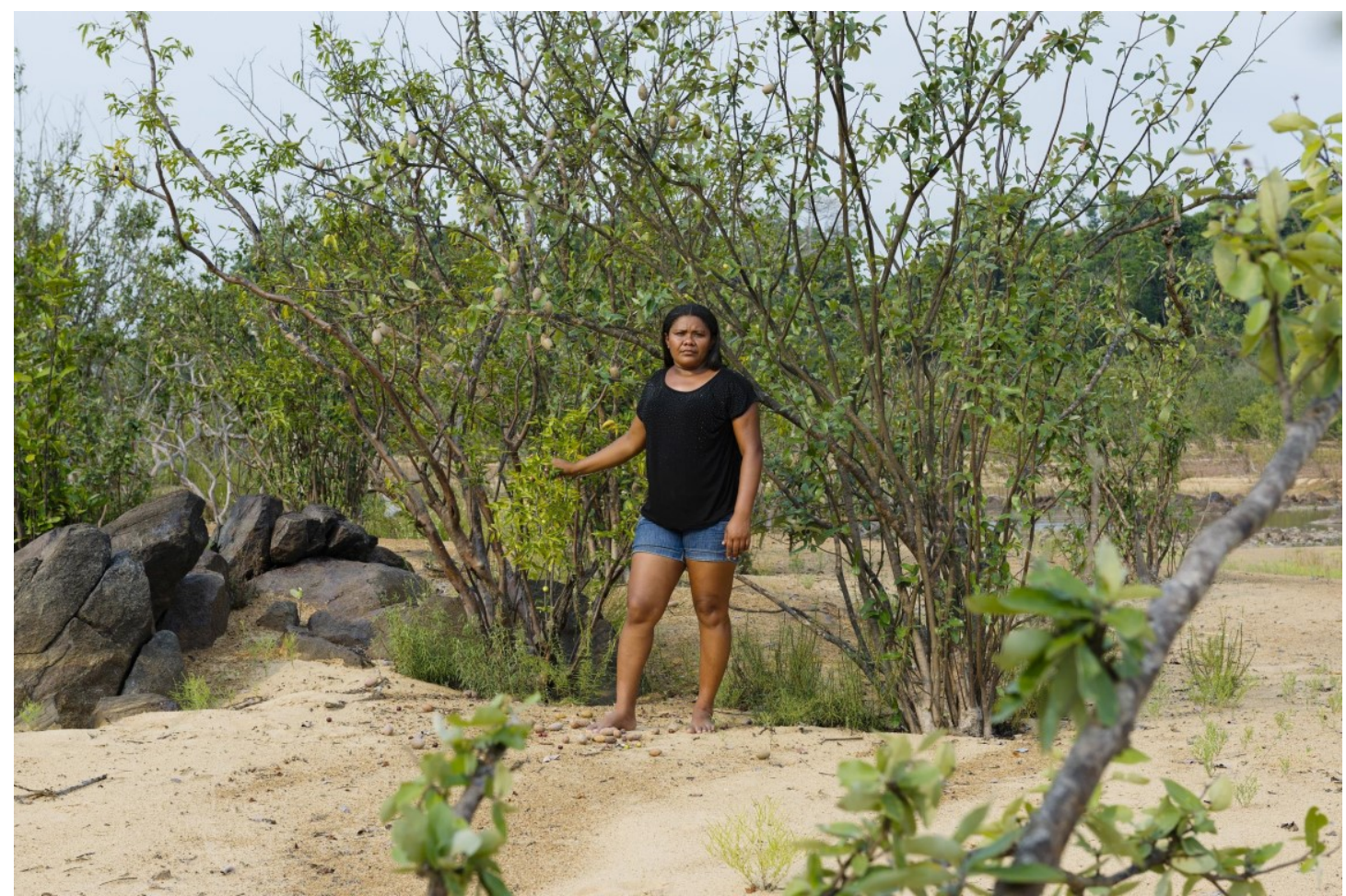

Figure 3 - Portrait of Maria Eliete (from Dead Water).

\section{Maria Eliete's feelings: desperation and sorrow}

The object chosen: native trees whose fruits can no longer fall in the Water and feed fish which depend on them to survive but rather drop from these trees on the exposed sand riverbank of the stretch of the Xingu River located downstream of the Pimental dam (stretch where Eliete's home, the Paquiçamba Indigenous Reserve, is situated).

\footnotetext{
${ }^{13}$ The Pimental dam (the major dam of the Belo Monte dam complex) sluice gates were closed for the first time, in November 2015.
} 
Location chosen: the dam-led exposed riverbank of the Xingu River, where the Paquiçamba Indigenous Reserve (Eliete's home) is located.

(C) Maria Eliete Felix Juruna and Marilene Ribeiro 2016

In their turn, Delcilene and Maria das Graças (Delcilene's mother), also participants from my fieldwork in the Belo Monte dam area, chose to be portraited at their former place of livingCashew Island. The island, as can be inferred from its name, was full of cashew trees, especially in Maria das Graças and Delcilene's backyard. It featured sandbanks (locally known as 'beaches') too, where the family enjoyed their free time. Cashew Island, along with dozens of others, was partially submerged as the reservoir of the Belo Monte hydropower plant complex started to be filled.

They choose to be portrayed at Cashew Island because, as Delcilene highlights, "Our island, our sand beaches, our trees, our home... all have gone.” and Maria das Graças adds: "Because the islands, the trees, they all died, everything is dead. It looks like a backwood in the backlands [sertão]. Right? The ones where you only see stumps, which we see on the news [on] Sunday. It's the same thing."

According to Delcilene and Maria das Graças, the whole region where they were born and bred is no longer recognisable:

[...] Girl, just, as the saying goes, when you look, it's just sadness, right. When we went there the first time [after the reservoir filling event], we arrived at the middle of the river channel, in Paratizinho, near Daniel's place [a site where a person named Daniel used to live], I looked to one side then to the other, and said, 'That's the way, but it's not through here.' I sat there on the bench, [along with] her [Delcilene] at the stern of the boat, then I said, 'Neném [Delcilene's nickname] - I told her - where are we, dear God?' And she said 'Mama, even I don't know.' Then when we spotted the hill, I said, 'That hill, is it Arundina's hill, right?' Then the pilot said, 'It is, Maria. That's [where] Alta beach used to be' - there was a bush at the tip of Alta beach; that was when I recognised it, that the tip was a beach, where that farm was - there was a beach right at the beginning, at the tip - but the rest I didn't recognise at all. She [Delcilene] said, 'Mother, that island was the island we lived on [Cashew Island]'. I said, 'No, girl,' she said, 'Yes, Mother,' because I still could see the island. [...]

(Maria das Graças, interviewed on 15 October 2016)

However, they are concerned that I do not believe in what they say, because, according to them, the consortium in charge of the Belo Monte hydro project (the Norte Energia) has disseminated a different 'reality' about the local environment's 'health' and the affected people's 'wellbeing'.

[...] Maria das Graças - Even so, that's it: sometimes you [myself] can say, 'Ah, no, it's because many were angry with Norte Energia and do the interviews saying that no one liked it and such.' It is good to go there to look, to see and say, 'See, [Maria Das Graças] wasn't lying, look at the impact that the Norte Energia caused.' [...] Our story, the story which we tell, is not the same as [theirs]. ${ }^{14}$

\footnotetext{
${ }^{14}$ Maria das Graças' remark on the way the consortium in charge of the dam project has broadcasted the situation of the affected people. According to her and her daughter, Delcilene, these people, including Maria das Graças herself, have been treated as "rubbish" by the Norte Energia, which has denied them the right to another plot of land. Maria das Graças recalls the dialog she had with the staff of the compensation programme: "I said, 'I do not accept this. I won't be able to resettle my life with $\mathrm{R} \$ 12,400$ only!" [about $£ 3,000$ - the amount of money the company was offering for her to leave the place she was born and has lived ever since] and she [Magda] replied, 'You have two options: accept our offer
} 
Maria das Graças and Delcilene decide we can use the image-making process to tell this 'other' story. They choose to be portrayed on Cashew Island because they want me (and the viewers of Dead Water) to see with my own eyes the scope of the transformation the dam has caused in the area, to see with my own eyes that it is possible to raise the 'sertão' in the middle of an infinitude of Water (Fig. 4).
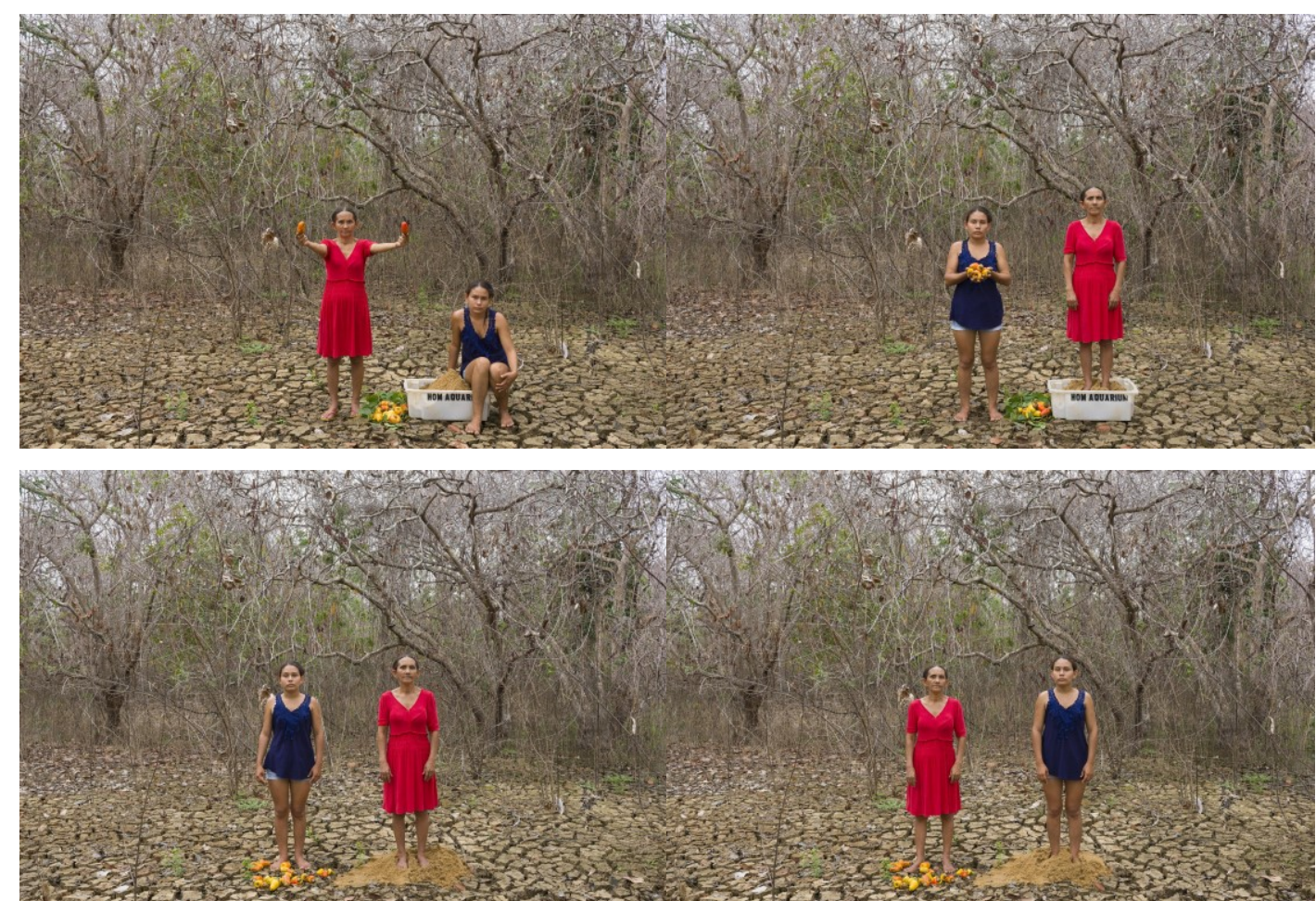

or rather remain here to be taken by the water." Also, according to Maria das Graças, the consortium affirms in its reports that the local environment is well and dwellers who had to move due to the Belo Monte hydro complex project have received proper support and found themselves in a better life condition now than before the project had started, which, for Maria, is not the same thing she and other displaced people have in fact experienced. 


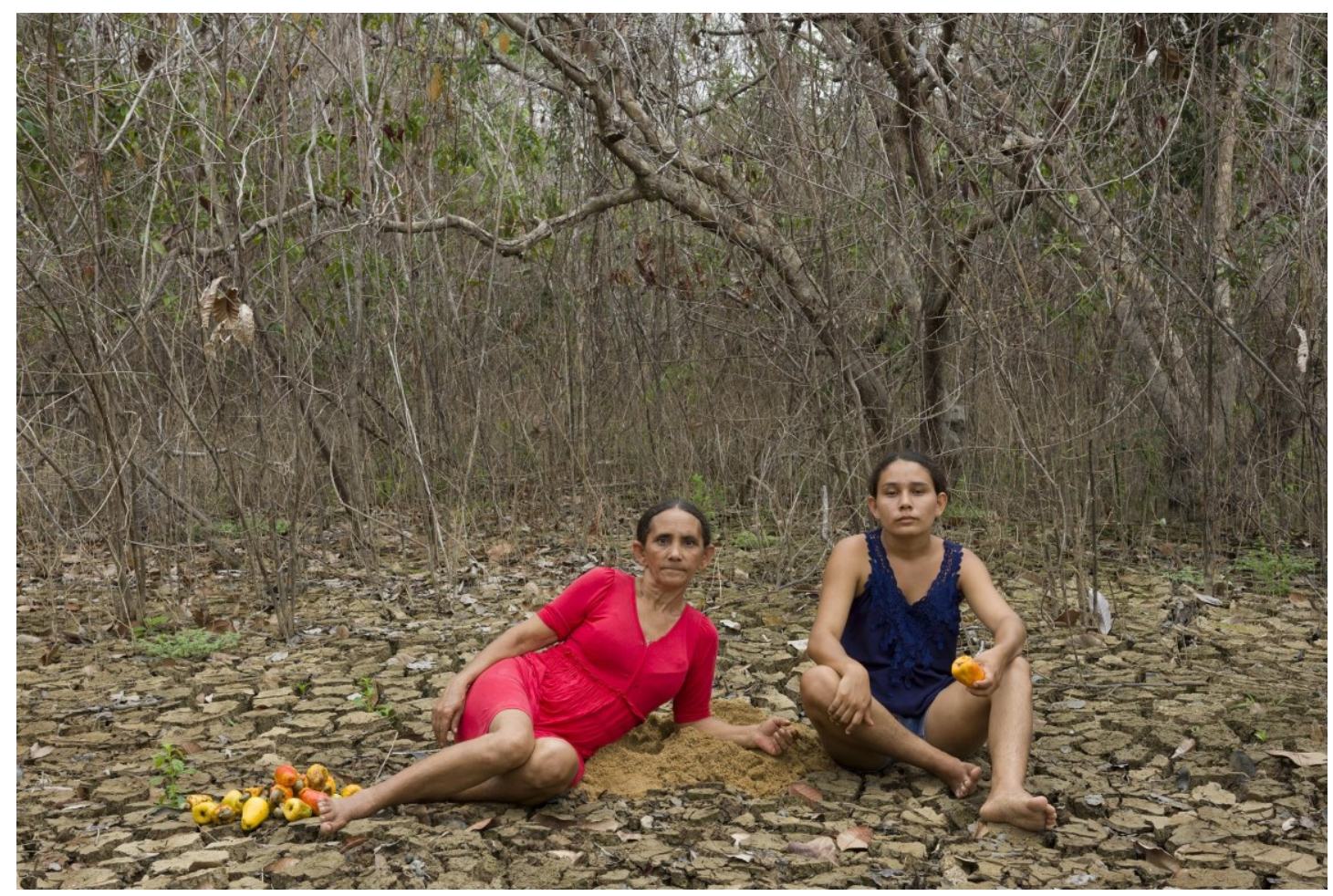

Figure 4 - Sequence of portraits of Maria das Graças and Delcilene (from Dead Water).

Delcilene's feelings: sorrow and humiliation

Maria das Graças' feeling: sorrow

Object chosen by Delcilene to represent her feeling: cashews (to represent the abundance in the region)

Object chosen by Maria das Graças (Delcilene's mother): sand (to represent the sand beaches)

Location chosen by both: their former backyard in Cashew Island (currently partly submerged by the Belo Monte dam).

Note dead cashew trees still standing in the background.

(C) Maria das Graças da Silva, Delcilene Gomes da Silva, and Marilene Ribeiro 2016

As I blend my views with the ones of riverside dwellers (the subjects portrayed, my collaborators in Dead Water), a more profound scene regarding the negative impact of dams, its complexity, its breadth, its roots are provided. We articulate another glance at this contentious matter (i.e. energy), which invites the beholder to a shift in the perception and assessment of wealth, wellbeing, nature, and development.

\section{THE BLOOM}

I understand photography as a unique mean that enables us, citizens, to have access to the other and to perceive, be touched by and absorb stories. As a result, photographs also have the capacity to demanding us to act. In this paper, I have employed experiences I have had with the participants and the audience of the practice-based research project Dead Water as the material from where my considerations on this theme unfold. From these and a growing understanding of theoretical texts, I conceive of some terrains in which photography could support improving social and environmental change in the twenty-first century.

1. Collaboration with the subject that is the focus of the visual inquiry is a way in which photography can flourish, and take a strong stance on the path towards social and environmental 
justice. In addition to other factors, I believe this to be an ethical approach for undertaking works of this kind. Working along with and close to the families that have collaborated with Dead Water has taught me an enormous amount, and has also brought so much relevant and crucial information to the work which could not be possible or be conceived using other forms of making (see also RIBEIRO, 2019, 2020). Also, as participants circulate what they have experienced during our encounter amidst their peers, I do the same amongst my peers, so that together we amplify and expand the reach of the work (so, the 'dissensus') further.

2. The society of the twenty-first century is shaped by photography and video: they are at the core of our behaviour and interaction with the world nowadays. It is naïve denying the influence of photographs as well as moving images upon our everyday life, in our opinions, thinking and responses regarding any subject matter. Noteworthily, transformations that are mediated by images in the present time unfold not only via traditional modes of dissemination of visual works (e.g. books, magazines, newspapers, exhibitions, talks) but they also grow from new platforms like those of social media, which, essentially, comprises a window to the visual culture which we are all embedded in. Bearing in mind the active role of the beholder as a protagonist of the act of photography, I understand that visual works that aim to advocate for social and environmental justice need to be versatile enough to fit in different platforms with their specific demands and ways of reaching (and touching) the viewer - e.g. online platforms set a totally different timing, and atmosphere for the viewer than a book, a film screening, an exhibition or a talk/discussion panel does, as each one of these affect the senses their particular way (as well as activating different parts of the brain) and at their given pace. By making use of as many platforms as possible that are suited to work, dialogical settings between the subject and the beholder can be triggered in a richer way, with more chances of success in the delivery of the message contained in the visual narrative. Versatile works can fit different interests and programmes too, thus being capable of reaching a broader audience. Also important is collaborating with and supporting social movements and NGOs, both committing to their claims/perspectives and providing them visual material that can strengthen their struggle for environmental and/or social justice, as these stakeholders have been vital in this context.

3. The 'photographer as expert' can play an important role in the legitimation of the discourse that is proposed to the beholder, as I have addressed on pp. 4-5. The presence of 'the expert' not only contributes to the potency of the work but also opens spaces for deeper debates on the factual side of the issue tackled (as the photographer holds specific knowledge that enables her/him to discuss appropriately scientific data and other aspects that are specific to that given discipline/field that is central to the context from where the subject inquired develops). This is, for instance, a tool that indigenous communities have been employing in their struggle for their rights: 
individuals from various communities in Brazil have graduated in Law, Anthropology, Social Sciences, Medicine, to name but a few, so that they can occupy spaces in where they can be heard as 'experts' also according to the 'standards' of the Western society and, therefore, can be respected in these other realms and debate themes that are relevant to them in a more egalitarian fashion.

According to University of Oxford's critical theory expert Nikolaj Lübecker (2013), in his analysis on the politics of images, "images, when used critically and imaginatively, can help to think through the essential questions of our time" (LÜBECKER, idem, p.405) as images consist of “a verb, not a noun” (LÜBECKER, 2013, p.405). In other words, images urge for a dialogue between viewer and subject to happen, they demand interpretation, digestion and response from the beholder, once in contact with the subject (a relationship which is mediated by them). This is the path through which I understand photography can commit to the pursuit of social and environmental justice. For this to take place, I argue that image-makers must conceive, shape, and set out bodies of works that nourish both subjects and beholders with energy to action, that welcome collaboration from both sides to happen, those elaborate ways of presenting these works that can welcome the audience to embark on this journey with both photographer and subject. It has to do with fascination (with seduction) before the discourse delivered by the work, but it also has to do with making room for and provoking reflection and reaction from the audience. How to create this fertile land where citizenry in its core, as well as a better future to all, can flourish is a challenge that I invite us image-makers, thinkers, subjects, audience - to engage with. There are multiple paths to achieve this, and they require creativity from artists and platforms that make artworks truly available to the public. It requires forms of communication and access that reach other audiences, beyond those from middle/upper class living in urban areas or in rich countries. I do not believe this is a utopia, as creativity, negotiation, dialogue and collaboration have always been central to enabling emancipation.

The Amazon, as we perceive and understand it to date, is the result of ecological processes that have shaped and sculpted the area for millennia. As such a unique and valuable place, it deserves to be cherished and a better future than this one that is currently in progress. Therefore, if image-making can be a tool in this movement for a more promising picture for the river basin, the forest and their inhabitants, it has to be employed for this purpose.

Dead Water was sponsored by the Brazilian CNPq PhD scholarship and also funded by the Royal Photographic Society Awards. It was undertaken with the support of the National Movement of People Affected by Dams (Movimento dos Atingidos por Barragens - MAB).

The author declares no competing interests. 


\section{REFERENCES}

ALEIXO, J.; CONDÉ, N. Quem são os Proprietários das Hidrelétricas da Amazônia? PINTO, J. R. L.; TAUTZ, C. (Coord). Rio de Janeiro: Instituto Mais Democracia, 2015. 52p.

ALLEMAND, D.; OSBORN, D. Ocean Acidification Impacts on Coral Reefs: From Sciences to Solutions. Regional Studies in Marine Science, v. 28, p. 1-8, 2019.

ANDREONI, M.; HAUSER, C. Fires in Amazon Rain Forest Have Surged This Year. The New York Times, published online on August 21 2019, unpaginated. Available in: https://www.nytimes.com/2019/08/21/world/americas/amazon-rainforest.html. Access in: 23 aug. 2019.

ARTAXO, P. Uma Nova era Geológica em Nosso Planeta: o Antropoceno? Revista USP, v. 103, p. 13-24, 2014.

AZOUlAY, A. The Civil Contract of Photography. Translated by Rela Mazali and Ruvik Danieli. New York: Zone Books, 2008. 586p.

AZOULAY, A. Civil imagination: a Political Ontology of Photography. Translated by Louise Bethlehem. London: Verso, 2012. 256p.

BARROS, C. No Maranhão, Cada Guardião da Floresta é um Paulino Guajajara. Publica, published online on 12 November 2019. Available in: https://apublica.org/2019/11/no-maranhaocada-guardiao-da-floresta-e-um-paulino-guajajara/. Access in: 06 feb. 2020.

BARROS, C.; SILVA, J. C.; DOMENICI, T. Land Conflicts and Destruction in the Brazilian Amazon. Publica, published online on November 16 2019. Available in: https://apublica.org/2019/11/land-conflicts-and-destruction-in-the-brazilian-amazon/. Access in: 14 de 2019.

BARTHES, R. Camera Lucida: Reflections on Photography. New York: Hill \& Wang, 1981. $119 \mathrm{p}$.

BASSETS, M. Bruno Latour: El Sentimiento de Perder el Mundo, Ahora, es Colectivo. El País, published online on 31 March 2019, unpaginated. Availale in: https://elpaiscom.cdn.ampproject.org/v/s/elpais.com/elpais/2019/03/29/ideas/1553888812_652680.amp.html?am p_js_v=a3\&amp_gsa $=1 \&$ usqp $=$ mq331AQIKAGwASDAAQE\%3D\#aoh=15877269154500\&referre $\mathrm{r}=\mathrm{https} \% 3 \mathrm{~A} \% 2 \mathrm{~F} \% 2 \mathrm{Fwww}$.google.com\&amp_tf=From $\% 20 \% 251 \% 24 \mathrm{~s} \&$ ampshare $=\mathrm{https} \% 3 \mathrm{~A} \% 2 \mathrm{~F}$ \%2Felpais.com\%2Felpais\%2F2019\%2F03\%2F29\%2Fideas\%2F1553888812_652680.html. Access in: 10 apr. 2020.

BOGRE, M. Photography as Activism: Images for Social Change. Oxford: Focal, 2012. 162p.

CONSTITUICIÓN DE LA REPÚBLICA DEL ECUADOR. Decreto Legislativo 0. Registro Oficial 449, October 20, p. 11-34, 2008.

CUNHA, E. Um Paraíso Perdido: Ensaios, Estudos e Pronunciamentos sobre a Amazônia. Rio de Janeiro: José Olympio, 1986. 280p.

DURAN, L. The Buzz on Climate Change: It's Bad for Bees. Conservation International, published online on August 19, 2017, unpaginated. Available in: 
https://www.conservation.org/blog/the-buzz-on-climate-change-its-bad-for-bees. Access in: 11 oct. 2017.

DOBLAS, R. Rotas do Saque: Violações e Ameaças à Integridade Territorial da Terra do Meio (PA). São Paulo: ISA - Instituto Socioambiental, 2015. 46p. Available in: https://www.socioambiental.org/sites/blog.socioambiental.org/files/nsa/arquivos/rotasdosaque_digit al02_0.pdf. Access in: 15 nov. 2015.

FEARNSIDE, P. M. Social Impacts of Brazil's Tucuruí dam. Environmental Management, v. 24, n. 4, p. 483-495, 1999.

FEARNSIDE, P. M. Environmental impacts of Brazil's Tucuruí dam: unlearned lessons for hydroelectric development in Amazonia. Environmental Management, v. 27, n.3, p. 377-396, 2001.

FEARNSIDE, P. M. Hidrelétricas na Amazônia: Impactos Ambientais e Sociais na Tomada de Decisões sobre Grandes Obras. Manaus: Editora do INPA, 2019. 148p.

FELLET, J.; COSTA, C. Imagens Mostram Avanço do Garimpo Ilegal na Amazônia em 2019. BBC News Brasil, published online on July 25 2019, unpaginated. Available in: https://www.bbc.com/portuguese/brasil-49053678. Access in: 01 aug. 2019.

FRIEDMAN, L. Trump Rule Would Exclude Climate Change in Infrastructure Planning. The New York Times, published online on January 03 2020, unpaginated. Available in: https://www.nytimes.com/2020/01/03/climate/trump-nepa-climate-change.html. Access in: 05 feb. 2020 .

GOODYEAR III, F. H. 'Photography Changes How We Record and Respond to Social Issues' In: HEIFERMAN, M. (Ed.) Photography changes everything. New York: Aperture and Smithsonian Institution, 2012. p. 160-176.

GRILL, G.; LEHNER, B.; THIERME, M; GEENEN, B.; TICKNER, D.; ANTONELLI, F.; BABU, S.; BORRELLI, P.; CHENG, L.; CROCHETIERE, H.; EHALT MACEDO, H.; FILGUEIRAS, R.; GOICHOT, M.; HIGGINS, J.; HOGAN, Z.; LIP, B; MCCLAIN, M. E.; MENG, J.; MULLIGAN, M.; NILSSON, C.; OLDEN, J. D.; OPPERMAN, J.J.; PETRY, P.; LIERMANN, C.R.; SÁENZ, L.; SALINAS-RODRÍGUEZ, S.; SCHELLE, P.; SCHMITT, R. J. P.; SNIDER, J.; TAN, F.; TOCKNER, K.; VALDUJO, P. H.; VAN SOESBERGEN, A; ZARFL, C. Mapping the world's free-flowing rivers, Nature, v. 569, p. 215-221, 2019.

GUDYNAS, E. Derechos de la Naturaleza - Ética Biocéntrica y Políticas Ambientales. Buenos Aires: Tinta Limón, 2015. 320p.

HELM, T. English Countryside at Risk from Boris Johnson's Planning Revolution. The Guardian, published online on July 04 2020. Available in: https://www.theguardian.com/environment/2020/jul/04/uk-countryside-at-risk-from-boris-johnsonsplanning-revolution. access in: 05 jul. 2020.

HODSON, D. The Politics of Documentary Photography: Three Theoretical Perspectives. Government and Opposition, p. 1-19, 2019.

INPA, IMAZON. Fenômeno dos Rios Voadores, 2018. Available in: https://riosvoadores.com.br/oprojeto/fenomeno-dos-rios-voadores/. Access in: 07 oct. 2018. 
IORIS, A. A. R. Amazon's Dead Ends: Frontier-Making the Centre. Political Geography, v. 65, p. 98-106, 2018.

ISA - INSTITUTO SOCIOAMBIENTAL. Os Povos Indígenas Isolados e as Obras de Infraestrutura que Ameaçam seus Territórios. São Paulo: ISA, 2018. Available in: https://www.socioambiental.org/sites/blog.socioambiental.org/files/nsa/arquivos/isolados_infraestru tura_nota_tecnica_1.pdf. Access in: 27 jun. 2019.

KUMAR, A.; SHARMA, M. P.; KUMAR, A. Green house gas emissions from hydropower reservoirs: policy and challenges. International Journal of Renewable Energy Research, v. 6, n. 2, p. 472-476, 2016.

LATOUR, B. Dónde Aterrizar: Cómo Orientarse en Política. Transl. Pablo Cuartas. Madrid: Taurus, 2019. 171p.

LEES, A. C.; PERES, C. A.; FEARNSIDE, P. M.; SCHNEIDER, M.; ZUANON, J. A. S. Hydropower and the future of Amazonian biodiversity. Biodiversity Conservation, v. 25, p. 451$466,2016$.

LINFIELD, S. The Cruel Radiance - Photography and Political Violence. London: University of Chicago Press, 2012. 344p.

LITTLE, P. E. Mega-development Projects in Amazonia - a Geopolitical and Socioenvironmental Primer. Lima: Derecho, Ambiente y Recursos Naturales - DAR, 2014. 96p.

LÜBECKER, N. 'The Politics of Images. Paragraph, v. 36. n. 3, p. 392-407, 2013.

MEISELAS, S. (2017). [Interview by email on 27 ${ }^{\text {th }}$ August 2017] Narmada. Directed by MANON OTT and GRÉGORY COHEN. 45 min. Paris: TS Productions, 2012.

NILSSON, C.; REIDY, C. A.; DYNESIUS, M.; REVENGA, C. Fragmentation and flow regulation of the world's large river systems. Science, v. 308, p. 405-408, 2005.

NOMBRE, A. ICOLD President answers Oxford misleading study. Yes, we need to build more large dams for water storage and energy for sustainable development! ICOLD, 2014. Available in: http://www.icold-cigb.net/share/article/4204/icold-president-answers-oxford-misleading-study.

Access in: 23 feb. 2015.

PONSETI, M.; LÓPEZ-PUJOL, J. The Three Gorges Dam Project in China: History and Consequences. Revista HMiC., v. 4, p. 151-188, 2006.

RANCIÈRE, J. The politics of Aesthetics. Translated by Gabriel Rockhill. London: Continuum, 2004. 128p.

RANCIÈRE, J. Dissensus: on Politics and Aesthetics. Edited and translated by Steven Corcoran. London: Continuum, 2010. 238p.

RIBEIRO, M. C. Dead Water - A Photography-based Inquiry into the Impact of Dams in Brazil. 2018. 502p. PhD Thesis [Creative Arts] - University for the Creative Arts. Farnham, UK. 2018. 
RIBEIRO, M. C. O ruir dos Rios e de suas Redes: Algumas Reflexões sobre Barragens e Hidrelétricas a partir do Trabalho Fotográfico Água Morta. Amazonia Latitude, published online on 10 September 2019. Available in: https://amazonialatitude.com/2019/09/10/o-ruir-dos-rios-e-desuas-redes/. Access in: 13 sep. 2019.

RIBEIRO, M. C. Rios-Desertos - Constatações durante o Processo de Construção do Trabalho Água Morta. Revista da UFMG, v. 26, n. 2, p. 152-167, 2020.

RIBEIRO, M. C.; BRANFORD S. The Hydroelectric Threat to the Amazon Basin. In: Gatehouse T. (Ed.) Voices of Latin America, Warwickshire: Practical Action Publishing, 2019. p. 121-146.

RICHTER, B. D.; POSTEL, S.; REVENGA, C.; SCUDDER, T.; LEHNER, B.; CHURCHILL, A.; CHOW, M. Lost in Development's Shadow: the Downstream Human Consequences of Dams. Water Alternatives, v. 3, n. 2, p. 14-42, 2010.

ROSLER, M. Around and Afterthoughts (on Documentary Photography) In: BOLTON, R. (Ed.) (1992) The context of Meaning: Critical Histories of Photography. Boston: MIT Press, 1981. p. $303-342$.

ROSLER, M. Post-documentary, Post-photography? In: ROSLER, M. Decoys and Disruptions: Selected Writings, 1975-2001. Cambridge, Mass: MIT Press, 2001, p. 207-244.

ROTH, K. China's Global Threat to Human Rights. In: Human Rights Watch. World Report 2020. New York: Seven Stories Press, 2020, p. 1-19.

SUBRAMANIAN, M. Anthropocene Now: Influential Panel Votes to Recognise Earth's New Epoch. Nature, published online on May 21 2019. Available in: https://www.nature.com/articles/d41586-019-01641-5. Access in: 13 feb. 2020.

TSIKATA, D. A. Living in the Shadow of Ghana's Dams: Long Term Responses of Downstream and Lakeside Akosombo and Kpong Communities. Leiden: Brill, 2006. 440p.

UN - UNITED NATIONS. Universal Declaration of Human Rights. Proclaimed by UN General Assembly Resolution 217A (III) of 10 December 1948. Available in: https://www.un.org/chinese/center/chbus/events/hurights/english.htm. Access in: 27 jul. 2010.

UN - UNITED NATIONS Murder of Brazilian Indigenous Leader a 'Worrying Symptom' of Land Invasion. United Nations - News, published online on July 29 2019, unpaginated. Available in: https://news.un.org/en/story/2019/07/1043401. Access in: 18 aug. 2019.

VIVEIROS DE CASTRO, E. Nenhum Povo é uma Ilha. In: Indigenous Peoples in Voluntary Isolation: Rethinking the Anthropological Approaches. Roundtable in Rio de Janeiro, Brazil, October 05 2018. Available in: https://www.youtube.com/watch?v=Q19C-Piq41Y. Access in: 13 mar. 2019.

XIE, S.; LI, Z.; LIU, J.; XIE, S.; WANG, H.; MURPHY, BR Fisheries of the Yangtze River Show Immediate Impacts of the Three Gorges Dam. Fisheries, v. 32, n. 7, p. 343-344, 2007. 
WATANABE, P. Salles Muda Política Ambiental do Brasil e Provoca Desmonte. Folha de S. Paulo, published online on December 24 2019, unpaginated. Available in: https:/www1.folha.uol.com.br/ambiente/2019/12/salles-muda-politica-ambiental-do-brasil-eprovoca-desmonte.shtml. Access in: 06 jan. 2020.

WATTS, J. Belo Monte, Brazil: The Tribes Living in the Shadow of a Megadam. The Guardian, published online on December 16 2014. Available in: https://www.theguardian.com/environment/2014/dec/16/belo-monte-brazil-tribes-living-in-shadowmegadam. access in: 21 dec. 2014.

ZARFL, C.; LUMSDON, A. E.; BERLEKAMP, J.; TYDECKS, L.; TOCKNER, K. A Global Boom in Hydropower Dam Construction. Aquatic Sciences, v. 77, n. 1, p. 161-170, 2014. 